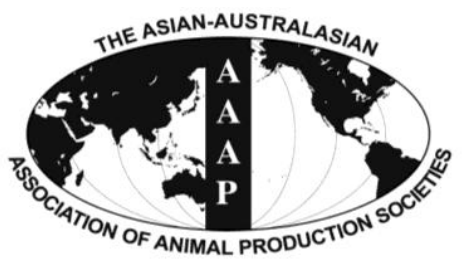

Asian Australas. J. Anim. Sci.

Vol. 26, No. 11 : 1569-1576 November 2013

http://dx.doi.org/10.5713/ajas.2012.12682

www.ajas.info

pISSN 1011-2367 elSSN 1976-5517

\title{
Effect of Vitamin E and Zinc Supplementation on Energy Metabolites, Lipid Peroxidation, and Milk Production in Peripartum Sahiwal Cows
}

\author{
G. Chandra*, A. Aggarwal, A. K. Singh, M. Kumar ${ }^{1}$, and R. C. Upadhyay \\ Dairy Cattle Physiology Division, National Dairy Research Institute, Karnal-132001 Haryana, India
}

\begin{abstract}
The study was conducted to evaluate the effect of vitamin $\mathrm{E}$ and zinc supplementation on energy metabolites, lipid peroxidation, and milk production in peripartum Sahiwal cows. For this, thirty-two pregnant dry Sahiwal cows were selected at sixty days prepartum and divided into four groups viz control, $\mathrm{T}_{1}, \mathrm{~T}_{2}$, and $\mathrm{T}_{3}$ of eight each. Group $\mathrm{T}_{1}$ were supplemented with zinc at 60 $\mathrm{ppm} / \mathrm{d} / \mathrm{cow}$, group $\mathrm{T}_{2}$ were supplemented with vitamin $\mathrm{E}$ at $1,000 \mathrm{IU} / \mathrm{d} / \mathrm{cow}$ and group $\mathrm{T}_{3}$ were supplemented with combination of vitamin $\mathrm{E}$ at $1,000 \mathrm{IU} / \mathrm{d} / \mathrm{cow}$ and zinc at $60 \mathrm{ppm} / \mathrm{d} / \mathrm{cow}$ during d 60 prepartum to $\mathrm{d} 90$ postpartum. Blood samples were collected on $\mathrm{d}$ $-60,-45,-30,-15,-7,-3,0,3,7,15,30,45,60,90$, and 120 with respect to day of parturition and analysed for glucose, non esterified fatty acid, and thiobarbituric acid reactive substance. Body condition score was maintained significantly better $(p<0.05)$ in $T_{3}$ than in the control, $\mathrm{T}_{1}$ and $\mathrm{T}_{2}$ groups. Overall glucose level was higher $(\mathrm{p}<0.05)$ in $\mathrm{T}_{3}$ than control, $\mathrm{T}_{1}$, and $\mathrm{T}_{2}$ groups. Levels of nonesterified fatty acid, and thiobarbituric acid reactive substance were lower $(\mathrm{p}<0.05)$ in $\mathrm{T}_{3}$ than control, $\mathrm{T}_{1}$, and $\mathrm{T}_{2}$ groups. Milk yield was higher $(\mathrm{p}<0.05)$ in $\mathrm{T}_{3}$ than control, $\mathrm{T}_{1}$, and $\mathrm{T}_{2}$ groups. In conclusion, the present study indicated that the supplementation of vitamin $\mathrm{E}$ and zinc in peripartum Sahiwal cows enhanced milk production by reducing negative energy balance. (Key Words: Body Condition Score, Glucose, Nonesterified Fatty Acid, Thiobarbituric Acid Reactive Substance, Sahiwal Cows)
\end{abstract}

\section{INTRODUCTION}

The dramatic increase in energy requirements needed for the onset of lactation in transition cows is often accompanied by a decrease in voluntary dry matter intake that causes a negative energy balance. Energy requirements that cannot be met by the diet must then rely on tissue energy reserves. Therefore, negative energy balance during the periparturient period causes mobilization of fat from tissue stores and the release of NEFA into the blood stream. Glucose tends to have an acute dip in concentration around the time of approaching parturition, signifying the increased demands of the foetus and mammary tissue (Grum et al., 1996; Stockdale and Roche, 2002). This is consistent with the drop in feed intake associated with parturition, decreasing the supply of nutrients such as glucose to the cow. There is an inverse relationship between glucose and nonesterified fatty acid (NEFA) (Reist et al., 2000). Blood glucose is depressed during times of elevated NEFA and

\footnotetext{
* Corresponding Author: Gulab Chandra. Tel: +91-8052968634, Fax: +91-184-2254751, E-mail: gulabdrvet@gmail.com

${ }^{1}$ Department of Animal Nutrition, DUVASU, Mathura 281001, U. P., India.
}

Submitted Dec. 10, 2012; Accepted Feb. 22, 2013; Revised Mar. 12, 2013
$\beta$-HBA, which is typical of the periparturient period (Ingvartsen and Andersen, 2000). Numerous studies clearly document an association between oxidative stress, elevated serum NEFA concentrations, reduced immunity, and increased disease susceptibility in dairy cattle during the periparturient period (Sordillo and Aitken, 2009; Contreras and Sordillo, 2011).

Dairy cows undergo massive metabolic adaptations during the onset of lactation, and it was postulated that some of these physiological events may negatively impact the health of the dairy cows (Sordillo et al., 2009). Lipid peroxidation is commonly measured in terms of thiobarbituric acid reactive substance (TBARS). Erythrocytes being rich in PUFA and being exposed to high concentration of oxygen are highly susceptible to peroxidation damage (Clemens and Waller, 1987; Balasinska, 2004). Oxidative stress can lead to increase in TBARS (Halliwell and Chirico, 1993), TBARS can induce a reduction of membrane fluidity and increase erythrocyte membrane fragility (Chen and Yu, 1994). The increase of TBARS immediately before and after calving confirms that cows during the transition period are under oxidative stress conditions (Kumaraguruparan et al., 2002; Bernabucci et al., 2005). The determination of lipid peroxidation products 
allows for the estimation of the intensity of this process; moreover, it can be used for the evaluation of oxidative stress severity (Halliwell and Whiteman, 2004).

Less research work has been done on effect of vitamin $\mathrm{E}$ (VE) and zinc (Zn) supplementation on energy metabolites, lipid peroxidation, and milk production in Sahiwal cows during peripartum. Therefore, the present experiment designed to investigate the effect of vitamin $\mathrm{E}$ and zinc supplementation on energy metabolites, lipid peroxidation, and milk production in peripartum Sahiwal cows.

\section{MATERIALS AND METHODS}

\section{Experiment design and feeding}

The experiment was conducted in cattle yard of the National Dairy Research Institute, Karnal, Haryana, India. Thirty-two pregnant Sahiwal cows were selected from the institute herd and randomly divided into four equal groups, 8 cows in each. The cows of all four groups were in similar body weight $(409 \pm 8.98,403 \pm 9.24,406 \pm 7.91$, and $398 \pm 7.09$ $\mathrm{kg}$ control, $\mathrm{T}_{1}, \mathrm{~T}_{2}$, and $\mathrm{T}_{3}$ groups, respectively), body condition score (BCS) (BCS: 3.00 $\pm 0.08,3.02 \pm 0.08$, $3.03 \pm 0.05$, and $3.05 \pm 0.08$ control, $\mathrm{T}_{1}, \mathrm{~T}_{2}$, and $\mathrm{T}_{3}$ groups, respectively), parity $(3.0 \pm 0.37,3.2 \pm 0.48,3.0 \pm 0.37$, and $3.2 \pm 0.31$ control, $\mathrm{T}_{1}, \mathrm{~T}_{2}$, and $\mathrm{T}_{3}$ groups, respectively) and milk yield. All cows of four groups were fed as per standard feeding practices. Each cow was offered $5 \mathrm{~kg}$ of green fodder (dry matter (DM) basis), $1 \mathrm{~kg}$ of silage (DM basis), and $3 \mathrm{~kg}$ of concentrate mixture daily (Table 1). Concentrate mixture contained (in grams per kilogram DM), wheat bran (200), maize (180), groundnut cake (145), barley (145), mustard cake (130), rice polishings (110), deoiled cottonseed cake (60), mineral mixture (20), and common salt (10). Eight cows were kept as control and eight cows were supplemented with zinc (in the form of zinc sulphate heptahydrate) at $60 \mathrm{ppm} / \mathrm{d} / \mathrm{cow}\left(\mathrm{T}_{1}\right)$, eight cows were supplemented with vitamin $\mathrm{E}$ at $1,000 \mathrm{IU} / \mathrm{d} / \mathrm{Cow}$ $\left(\mathrm{T}_{2}\right)$ and other eight cows were supplemented with a combination of vitamin $\mathrm{E}$ (in the form of DL-alphatocopheryl acetate) at $1,000 \mathrm{IU} / \mathrm{d} / \mathrm{cow}$ and zinc at 60 $\mathrm{ppm} / \mathrm{d} /$ cow $\left(\mathrm{T}_{3}\right)$ from $60 \mathrm{~d}$ prepartum to $90 \mathrm{~d}$ postpartum.
Vitamin E and zinc were accurately weighed daily and mixed with a small amount of concentrate and directly fed to the animals. The cows were kept under open housing system throughout the experiment, but $14 \mathrm{~d}$ before the expected date of calving, they were moved to a calving pen. Five days after parturition, the cows were moved to the paddock meant for lactating animals. Green fodder was offered ad libitum and $1 \mathrm{~kg}$ of concentrate mixture was given for every $2.5 \mathrm{~kg}$ of milk produced.

\section{Blood sampling}

Blood samples were collected from all cows in morning (6:30 AM) before feeding, by jugular vein puncture on -60 , $-45,-30,-15,-7,-3,0,3,7,15,30,45,60,90$, and $120 \mathrm{~d}$ in relation to expected date of calving with use of Vacutainer tubes (BD Franklin, USA) containing heparin as anticoagulating agent. Samples were brought to the laboratory in chilled iceboxes soon after collection and centrifuged at $1,200 \times \mathrm{g}$ at $4^{\circ} \mathrm{C}$ for $20 \mathrm{~min}$ to separate the plasma from packed erythrocytes. Plasma samples were stored at $-20^{\circ} \mathrm{C}$ until analysis of glucose, NEFA, and TBARS. The body condition score (BCS) of cows was established at the beginning of the study and then on the days of blood collection by the same person using a scale of 1 to 5 (Edmonson et al., 1989). Daily milk yield up to $120 \mathrm{~d}$ of lactation was recorded.

\section{Sample analysis}

Glucose was determined in plasma of cows by "Glucose 96 well assay kit" from Cayman Chemical Company, 1180 East Ellsworth Road Ann Arbour, MI 48108, USA. Intra and inter assay coefficients of variation were $2.54 \%$ and $9.35 \%$, respectively.

NEFA was determined in plasma of cows by "Bovine NEFA ELISA kit" from Cusabio Biotech Co., Ltd. China. Intra and inter coefficients of variation were $5.54 \%$ and $8.35 \%$, respectively.

TBARS was estimated in plasma of cows by "TBARS 96 well assay kit" from Cayman Chemical Company, 1180 East Ellsworth Road Ann Arbour, MI 48108, USA. Intra and inter coefficients of variation were $4.74 \%$ and $9.23 \%$,

Table 1. Approximate daily Vitamin E (mg) zinc (ppm) intake of different groups of Sahiwal cows

\begin{tabular}{|c|c|c|c|c|c|c|c|c|}
\hline \multirow{3}{*}{ Days } & \multicolumn{8}{|c|}{ Group } \\
\hline & \multicolumn{2}{|c|}{ Control } & \multicolumn{2}{|c|}{$\mathrm{T} 1$} & \multicolumn{2}{|c|}{$\mathrm{T} 2$} & \multicolumn{2}{|c|}{$\mathrm{T} 3$} \\
\hline & VE & $\mathrm{Zn}$ & VE & $\mathrm{Zn}$ & $\mathrm{VE}$ & $\mathrm{Zn}$ & VE & $\mathrm{Zn}$ \\
\hline $5 \mathrm{~kg}$ mixed green fodder & 150 & 25 & 150 & 25 & 150 & 25 & 150 & 25 \\
\hline $1 \mathrm{~kg}$ silage & 6 & 20 & 6 & 20 & 6 & 20 & 6 & 20 \\
\hline $3 \mathrm{~kg}$ concentrate mixture & 55 & 140 & 55 & 140 & 55 & 140 & 55 & 140 \\
\hline Supplement & 0 & 0 & 0 & 60 & 1,000 & 0 & 1,000 & 60 \\
\hline Total & 211 & 185 & 211 & 245 & 1,211 & 185 & 1,211 & 245 \\
\hline
\end{tabular}

$\mathrm{T} 1=$ Zinc treated group, T2 = Vitamin E treated group, T3 = Zinc+vitamin E treated group.

$\mathrm{VE}=$ Vitamin $\mathrm{E}, \mathrm{Zn}=$ Zinc . 
Table 2. Dry matter intake, body condition score, glucose, non esterifies fatty acid (NEFA), thiobarbituric acid substance (TBARS) prepartum, at parturition and postpartum, and milk yield along with p-values of vitamin $\mathrm{E}$ and zinc supplemented cows and non supplemented control cows

\begin{tabular}{|c|c|c|c|c|c|c|c|c|}
\hline \multirow{2}{*}{ Parameters } & \multicolumn{4}{|c|}{ Group } & \multirow{2}{*}{ SEM } & \multicolumn{3}{|c|}{$\mathrm{p}$-value } \\
\hline & Control & $\mathrm{T} 1$ & $\mathrm{~T} 2$ & $\mathrm{~T} 3$ & & Group & Day & Groups $\times$ Days \\
\hline \multicolumn{9}{|c|}{ Dry matter intake (kg) } \\
\hline Prepartum & $8.46^{\mathrm{aA}}$ & $8.55^{\mathrm{abA}}$ & $8.66^{\mathrm{abA}}$ & $8.76^{\mathrm{bA}}$ & 0.07 & $<0.001$ & $<0.001$ & 0.986 \\
\hline At parturition & $7.60^{\mathrm{aB}}$ & $7.81^{\mathrm{abB}}$ & $7.84^{\mathrm{bB}}$ & $8.22^{\mathrm{cB}}$ & 0.10 & & & \\
\hline Postpartum & $10.92^{\mathrm{aC}}$ & $11.14^{\mathrm{abC}}$ & $11.09^{\mathrm{bC}}$ & $11.29^{\mathrm{bC}}$ & 0.11 & & & \\
\hline \multicolumn{9}{|c|}{ Body condition score } \\
\hline Prepartum & $3.0^{\mathrm{aA}}$ & $3.1^{\mathrm{bA}}$ & $3.1^{\mathrm{bA}}$ & $3.2^{\mathrm{cA}}$ & 0.03 & $<0.001$ & $<0.001$ & 0.001 \\
\hline At parturition & $2.8^{\mathrm{aB}}$ & $2.9^{\mathrm{bB}}$ & $2.9^{\mathrm{bB}}$ & $3.1^{\mathrm{cB}}$ & 0.06 & & & \\
\hline Postpartum & $2.2^{\mathrm{aC}}$ & $2.5^{\mathrm{bC}}$ & $2.5^{\mathrm{bC}}$ & $2.7^{\mathrm{cC}}$ & 0.03 & & & \\
\hline \multicolumn{9}{|l|}{ Glucose $(\mathrm{mg} / \mathrm{dL})$} \\
\hline Prepartum & $48.31^{\mathrm{aA}}$ & $50.85^{\mathrm{aA}}$ & $51.04^{\mathrm{abA}}$ & $53.73^{\mathrm{bA}}$ & 1.36 & $<0.001$ & $<0.001$ & 1.000 \\
\hline At parturition & $35.87^{\mathrm{aB}}$ & $40.13^{\mathrm{bB}}$ & $39.24^{\mathrm{bB}}$ & $45.27^{\mathrm{cB}}$ & 1.44 & & & \\
\hline Postpartum & $43.69^{\mathrm{aC}}$ & $48.31^{\mathrm{bA}}$ & $48.52^{\mathrm{bA}}$ & $51.37^{\mathrm{cA}}$ & 0.96 & & & \\
\hline \multicolumn{9}{|l|}{ NEFA $(\mu \mathrm{M})$} \\
\hline Prepartum & $138.96^{\mathrm{aA}}$ & $123.26^{\mathrm{abA}}$ & $124.08^{\mathrm{abA}}$ & $110.93^{\mathrm{bA}}$ & 8.09 & $<0.001$ & $<0.001$ & 0.909 \\
\hline At parturition & $274.90^{\mathrm{aB}}$ & $257.64^{\mathrm{bB}}$ & $264.77^{\mathrm{bB}}$ & $219.42^{\mathrm{cB}}$ & 21.22 & & & \\
\hline Postpartum & $275.72^{\mathrm{aB}}$ & $230.90^{\mathrm{bC}}$ & $224.91^{\mathrm{bC}}$ & $178.32^{\mathrm{cC}}$ & 12.62 & & & \\
\hline \multicolumn{9}{|l|}{ TBARS $(\mu \mathrm{M})$} \\
\hline Prepartum & $1.62^{\mathrm{A}}$ & $1.34^{\mathrm{A}}$ & $1.36^{\mathrm{A}}$ & $1.25^{\mathrm{A}}$ & 0.10 & $<0.001$ & $<0.001$ & 1.000 \\
\hline At parturition & $2.43^{\mathrm{aB}}$ & $2.04^{\mathrm{aB}}$ & $1.99^{\mathrm{aB}}$ & $1.71^{\mathrm{bB}}$ & 0.31 & & & \\
\hline Postpartum & $3.01^{\mathrm{aC}}$ & $2.46^{\mathrm{bC}}$ & $2.41^{\mathrm{bC}}$ & $1.96^{\mathrm{cC}}$ & 0.13 & & & \\
\hline Milk yield (kg) & $6.86^{\mathrm{a}}$ & $7.75^{\mathrm{b}}$ & $7.78^{\mathrm{b}}$ & $8.57^{\mathrm{c}}$ & 0.65 & $<0.001$ & $<0.001$ & 1.000 \\
\hline
\end{tabular}

Mean \pm SE with different superscript in small letter in a row and capital letter in column differ significantly $(\mathrm{p}<0.05)$.

$\mathrm{T} 1=$ Zinc treated group, $\mathrm{T} 2=$ Vitamin $\mathrm{E}$ treated group, $\mathrm{T} 3=$ Zinc+vitamin $\mathrm{E}$ treated group

respectively.

\section{Statistical analysis}

Data were analyzed using the MIXED procedure of statistical software package SPSS version 19 (SPSS for windows, V19.0; SPSS Inc., Chicago, IL, USA). Repeated measures on DMI, BCS, energy metabolites (glucose and NEFA), TBARS, and milk yield were analyzed using mixed model analyses. The statistical model was used to estimate sampling day effect, treatment group (vitamin E and zinc supplementation), and their interaction:

$$
Y_{i j k}=\mu+T_{i}+D_{j}+(T \times D)_{i j}+e_{i j k}
$$

Where, $\mathrm{Y}_{\mathrm{ijk}}=$ dependent variable; $\mu=$ overall mean of the population; $T_{i}=$ mean effect of the treatment group $(V E$ and $\mathrm{Zn}$ supplementation) $(\mathrm{i}=1, \ldots .4) ; \mathrm{D}_{\mathrm{j}}=$ mean effect of day of sampling $(j=1, \ldots . .15)$ with day as a repeated factor; $(\mathrm{T} \times \mathrm{D})_{\mathrm{ij}}=$ effect of the interaction between effect of treatment group and $\mathrm{d}$ of sampling; $\mathrm{e}_{\mathrm{ijk}}=$ unexplained residual element assumed to be independent and normally distributed.

Briefly, the model included group, day, and their interaction as fixed effects, and animal within group as the random effect. The pair-wise comparison of means was carried out using 'Tukey's Multiple Range Test'. Different parameters (NEFA, glucose, BCS and TBARS) were correlated with Pearson's correlation method.

\section{RESULTS}

The DMI decreased during prepartum period and was lowest on the day of calving in all the four groups (Table 2). DMI started increasing after parturition due to the need of higher energy for production of milk (Table 2).

Changes of BCS in each of the 4 groups of cows are reported in Figure 1. At the beginning of the study (d 60 prepartum), BCS was similar in all the cows (BCS: control $3.0 \pm 0.08, \mathrm{~T}_{1} 3.0 \pm 0.08, \mathrm{~T}_{2} 3.0 \pm 0.05$, and $\left.\mathrm{T}_{3} 3.0 \pm 0.08\right)$. The control group showed higher $(\mathrm{p}<0.05)$ BCS reduction during pre and postpartum period of study.

Changes of glucose in each of the 4 groups of cows are reported in Figure 2. Plasma concentration of glucose began to decrease steadily from $60 \mathrm{~d}$ before calving and reached minimum on d 3 postpartum in all four groups, which showed a decrease of $37.63 \%, 31.01 \%, 32.05 \%$, and $22.18 \%$ in control, $\mathrm{T}_{1}, \mathrm{~T}_{2}$, and $\mathrm{T}_{3}$ groups, respectively. Plasma glucose levels were higher $(\mathrm{p}<0.05)$ in $\mathrm{T}_{3}$ than its 


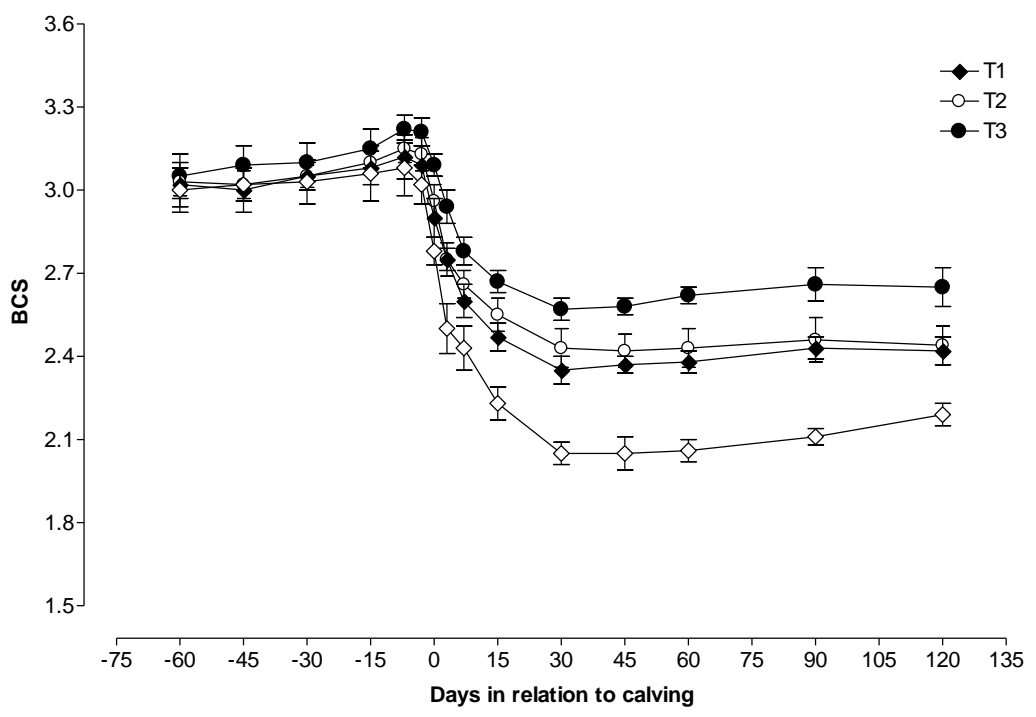

Figure 1. Changes in body condition score (BCS) during pre and postpartum period in control, $\mathrm{T}_{1}$ (zinc treated), $\mathrm{T}_{2}$ (vitamin $\mathrm{E}$ treated) and $\mathrm{T}_{3}$ (zinc+vitamin $\mathrm{E}$ treated) groups.

levels in control, $T_{1}$, and $T_{2}$, groups on all days of pre and postpartum except d 45, 60 prepartum, and d 120 postpartum. Plasma glucose showed higher $(\mathrm{p}<0.05)$ values prepartum compared with level registered at parturition and postpartum in all the four groups, whereas, pre and postpartum plasma glucose levels was nearly similar in $T_{1}$, $\mathrm{T}_{2}$, and $\mathrm{T}_{3}$ groups cows (Table 2).

During postpartum and on the day of parturition, plasma NEFA was observed to be significantly $(\mathrm{p}<0.05)$ lower in $\mathrm{T}_{3}$ than its level in control, $\mathrm{T}_{1}$, and $\mathrm{T}_{2}$ groups (Table 2). On the day of parturition plasma NEFA levels were higher $(\mathrm{p}<0.05)$ than values observed during pre and postpartum period in all four groups except in control where values observed during postpartum and on the day of parturition was nearly similar (Table 2). Plasma NEFA levels began to increase slightly from $60 \mathrm{~d}$ before calving and reached to maximum level at $\mathrm{d} 3$ postpartum, observed higher $(\mathrm{p}<0.05)$ in control than $\mathrm{T}_{1}, \mathrm{~T}_{2}$, and $\mathrm{T}_{3}$ groups. After calving the level decreased up to d 120 postpartum in all the groups, but decreasing levels was observed to be lower in control followed by $T_{1}$, $\mathrm{T}_{2}$, and $\mathrm{T}_{3}$. Plasma NEFA level was increased to $289.21 \%$, $274.02 \%, 240.75 \%$ and $203.54 \%$ on d 3 postpartum in comparison to its level on $60 \mathrm{~d}$ prepartum in control, $\mathrm{T}_{1}, \mathrm{~T}_{2}$, and $\mathrm{T}_{3}$ groups, respectively (Figure 3 ). NEFA was negatively correlated with glucose $(p<0.01, r=-0.53)$ and positively correlated with BCS decline $(\mathrm{p}<0.05, \mathrm{r}=0.44)$.

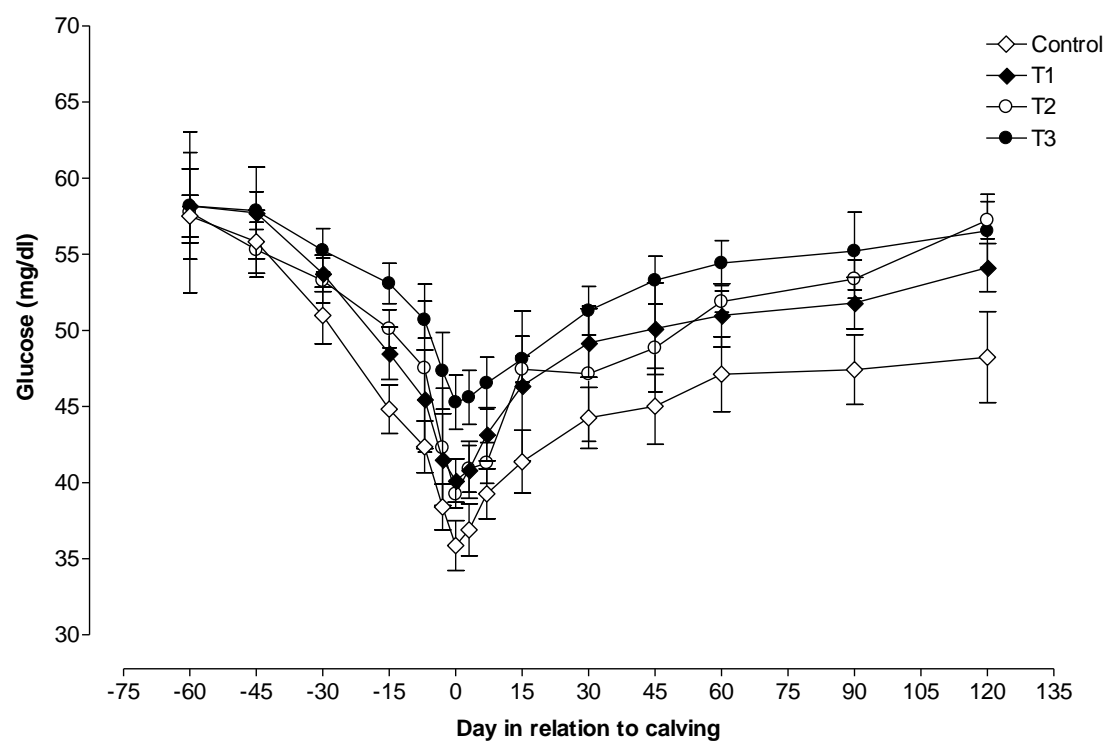

Figure 2. Changes in plasma glucose during pre and postpartum period in control, $T_{1}$ (zinc treated), $T_{2}$ (vitamin $E$ treated) and $T_{3}$ (zinc+vitamin E treated) groups. 


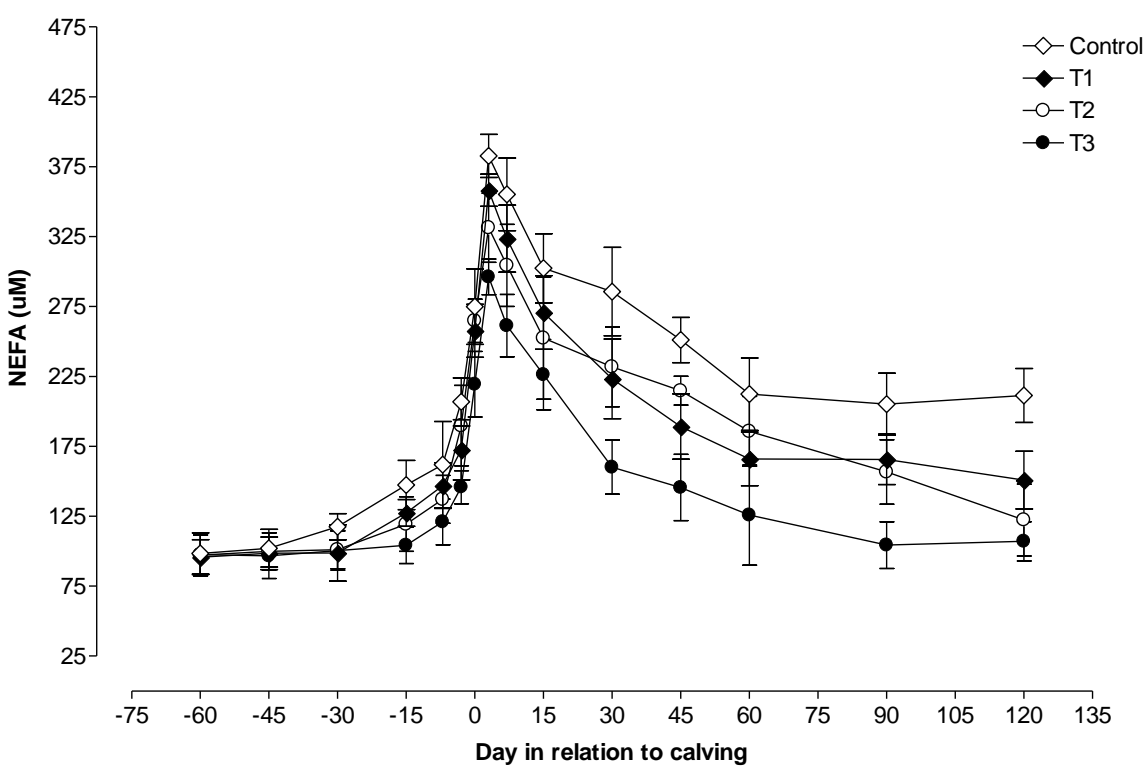

Figure 3. Changes in plasma non esterifies fatty acid (NEFA) during pre and postpartum period in control, $\mathrm{T}_{1}$ (zinc treated), $\mathrm{T}_{2}$ (vitamin E treated) and $\mathrm{T}_{3}$ (zinc+vitamin $\mathrm{E}$ treated) groups.

Plasma TBARS began to increased slightly from $60 \mathrm{~d}$ before calving and reached maximum at $\mathrm{d} 30$ postpartum in control whereas maximum at $15 \mathrm{~d}$ postpartum in $\mathrm{T}_{1}, \mathrm{~T}_{2}$, and $\mathrm{T}_{3}$ groups. After that value decreased up to $\mathrm{d} 120$ postpartum in all four groups, but decreasing level was observed lower in control followed by $\mathrm{T}_{1}, \mathrm{~T}_{2}$, and $\mathrm{T}_{3}$ groups (Figure 4). Plasma TBARS levels were found higher $(\mathrm{p}<0.05)$ in $\mathrm{T}_{3}$ than control, $\mathrm{T}_{1}$, and $\mathrm{T}_{2}$ groups, in its levels on all days of pre and postpartum except d 45 and 60 prepartum. Plasma TBARS showed lower $(\mathrm{p}<0.05)$ values during pretpartum compared with those observed during parturition and postpartum period in all four groups. But postpartum plasma TBARS level was lower $(\mathrm{p}<0.05)$ in $\mathrm{T}_{3}$ compared with those observed in $\mathrm{T}_{1}, \mathrm{~T}_{2}$, and control groups (Table 2). TBARS was negatively correlated with BCS $(\mathrm{p}<0.01, \mathrm{r}=-0.41)$.

The overall value of milk yield was observed higher $(\mathrm{p}<0.05)$ in $\mathrm{T}_{3}$ in comparison to its level in control, $\mathrm{T}_{1}$, and $\mathrm{T}_{2}$ groups (Table 2). Overall milk yield increased by $12.97 \%, 13.41 \%$, and $24.93 \%$ in $\mathrm{T}_{1}, \mathrm{~T}_{2}$, and $\mathrm{T}_{3}$ groups,

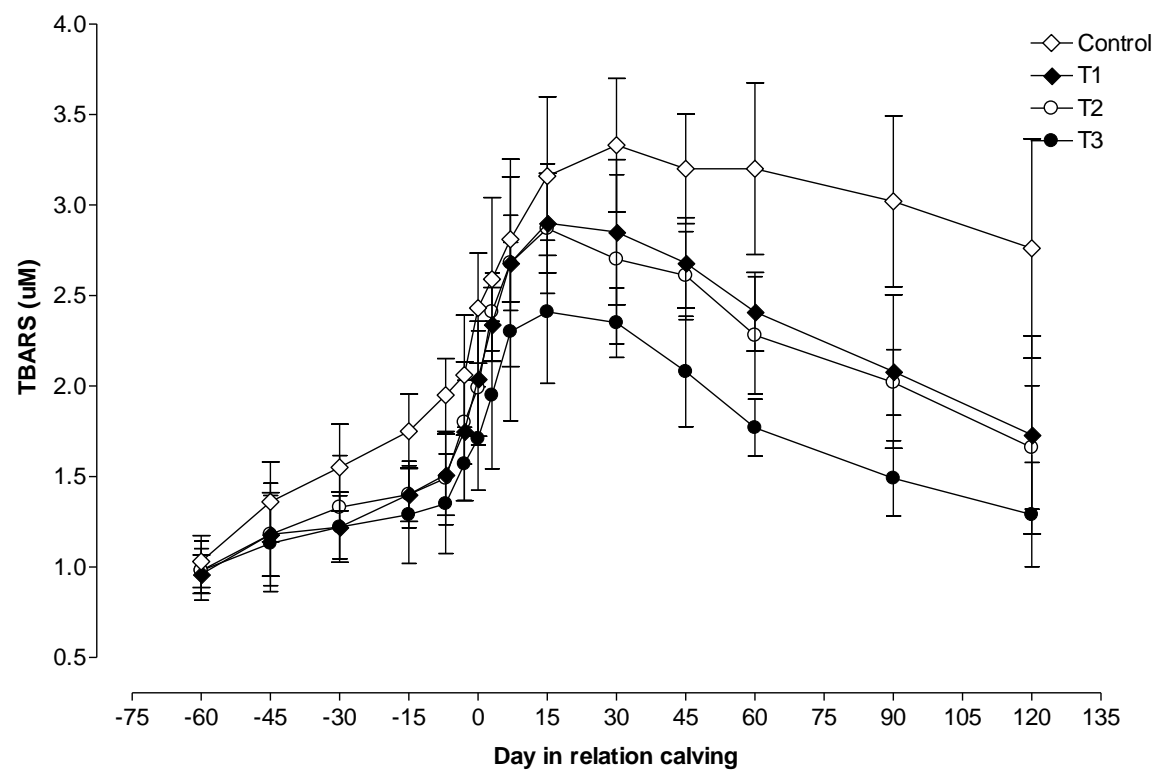

Figure 4. Changes in plasma thiobarbituric acid reactive substance (TBARS) during pre and postpartum period in control, $\mathrm{T}_{1}$ (zinc treated), $\mathrm{T}_{2}$ (vitamin $\mathrm{E}$ treated) and $\mathrm{T}_{3}$ (zinc+vitamin $\mathrm{E}$ treated) groups. 
respectively, in comparison to control.

\section{DISCUSSION}

DMI is influenced by stage of transition phase, body condition score and parity (Hayirli et al., 2002). Most cows consume more DMI during first three weeks after calving (Ingvartsen and Andersen, 2000). In the present experiment, DMI decreased around peripartum due to significant $(\mathrm{p}<0.05)$ increase in oxidative stress around calving as also observed by Castillo et al. (2005) and Grummer et al. (2004). DMI increased ( $\mathrm{p}<0.05)$ in VE supplemented group in comparison to non supplemented group during periparturient period (Chandra and Aggarwal, 2010).

Adipose tissue mobilization typically begins prepartum with the commonly observed intake depression during the last 3 wks of gestation (Bertics et al., 1992). It has been hypothesized that cows with less body condition will sustain intake longer and experience an abrupt drop in DMI just prior to calving (Hayirli et al., 2002). Tissue mobilization is usually most active from $14 \mathrm{~d}$ prepartum to 35 d postpartum (Komaragiri et al., 1998). Park et al. (2010) demonstrated the importance of appropriate nutrition during this period to minimize loss of body condition. Maurya (2011) reported that VE and $\mathrm{Zn}$ supplementation during dry period and early lactation minimised the loss of body condition, as found in our experiment.

In present study, plasma glucose levels were found to decrease towards calving and decrease was more at calving and then increased slightly after few days of calving. Similar changes in glucose level during periparturient period were also reported by others (Dann et al., 2005; Maurya, 2011; Chandra et al., 2012). Propionate production from the low DMI during the early postpartum period is insufficient to synthesize the total amount of glucose needed. Therefore, the concentration of glucose decreased following parturition as observed in our studies. Plasma glucose concentration are important energy metabolites and higher concentrations in treatment groups could be due to more feed intake attributed to VE and thus higher levels of glucose (LeBlanc et al., 2004). Around parturition glucose concentration decreased and NEFA concentration increased due to lipolysis, which acts as alternative energy source (Shehab-El-Deen et al., 2010). This is supported by the significant negative correlation coefficient between glucose and NEFA concentration found in the present study.

Bernabucci et al. (2005) reported that peripartum cows with elevated plasma NEFA levels also had higher plasma levels of reactive oxygen metabolites, but lower levels of antioxidants. Positive correlations was observed between BCS decline, plasma NEFA levels, and increased incidence of health problems in dairy cattle as a consequence of accelerated BCS drop during the transition period (Buckley et al., 2003; Kim and Suh, 2003). Concentration of NEFA was lower in vitamin $\mathrm{E}$ and zinc treated groups in comparison to control groups, also reported by Bouwstera et al. (2008), Maurya (2011), and Chandra et al. (2012). As NEFA concentrations elevated, there was increased disease susceptibility in dairy cattle during the periparturient period (Sordillo and Aitken, 2009; Contreras and Sordillo, 2011).

Thiobarbituric acid reactive substances (TBARS) is an indicative of lipid peroxidation and increased levels after calving indicates the imbalance between oxidants and antioxidants (Bernabucci et al., 2005; Castillo et al., 2005; Bouwstra et al., 2010). The increase in TBARS level after calving was in accordance with reports given by Halliwell and Chirico (1993) and Bernabucci et al. (2002). They observed that the oxidative stress leads to increase in erythrocyte TBARS. The increase of TBARS before and after calving indicates that periparturient cows were under oxidative stress (Balasinska, 2004; Halliwell and Whiteman, 2004). In the present study lipid peroxidation (plasma MDA production) was higher in early lactating cows than advanced pregnant cows, which was nearly double. The findings of our study are in corroboration with the reports of Saleh et al. (2007) and Sordillo et al. (2007); they used TBARS values as a marker of lipid peroxidation in cattle. Oxidative stress in cows is a contributory factor to increase disease susceptibility (Sordillo, 2005), since metabolic demands associated with late pregnancy, parturition and initiation of lactation would be expected to increase the production of reactive oxygen species (ROS), resulting oxidative stress. In the present study TBARS concentration was lower in VE and $\mathrm{Zn}$ treated groups than control as also observed by Maurya (2011), which was probably due to the vitamin $\mathrm{E}$ and zinc neutralize the formation of ROS during pre and postpartum. The lower levels of TBARS in VE treated group was also supported by Bouwstra et al. (2010).

In the present experiment, the milk yield was found to be higher in $T_{3}$ followed by $T_{2}, T_{1}$ and control indicating that $\mathrm{VE}$ and $\mathrm{Zn}$ supplementation increased the milk yield. This was attributed to increase in DMI and decrease in the incidence of subclinical and clinical mastitis in VE and $\mathrm{Zn}$ supplemented groups (Chawla and Kaur, 2004; Maurya, 2011). Griffiths et al. (2007), supplementing cows with CTM (providing daily $360 \mathrm{mg} \mathrm{Zn,} 200 \mathrm{mg} \mathrm{Mn}, 125 \mathrm{mg} \mathrm{Cu}$ as amino acid complexes and $12 \mathrm{mg}$ cobalt (Co) from $\mathrm{Co}$ glucoheptonate) resulted in a $6.3 \%$ increase in milk production. Increase in milk production might be partially attributed to role of $\mathrm{Zn}$ in the cell division and protein synthesis, as increasing $\mathrm{Zn}$ can improve integrity of epithelial tissue, such as teats and udder tissue (Sobhanirad et al., 2010).

The number of mastitis cases was $4,1,0$, and 0 in control, $\mathrm{T}_{1}, \mathrm{~T}_{2}$, and $\mathrm{T}_{3}$ groups, respectively. In present experiment $\mathrm{VE}$ and $\mathrm{Zn}$ supplementation reduced the 
mastitis cases, as also reported by Maurya (2011). In general, free radicals cause cell damage and might influence the functions of immune cells resulting in increased mastitis risk (Politis et al., 2004; Sordillo and Aitken, 2009). Bouwstra et al. (2010) found that cows that developed clinical mastitis in early lactation had higher levels of ROM and MDA two week prepartum.

The numbers of animals having retained fetal membrane were $4,1,1$ and 0 in control, $\mathrm{T}_{1}, \mathrm{~T}_{2}$ and $\mathrm{T}_{3}$ groups, respectively. Miller et al. (1993) suggested that cows with retained placenta had lower total antioxidant status. Panda et al. (2006) reported $17 \%$ reduction in RFM in VE supplemented in comparison to non supplemented group. This effect is consistent with findings from a meta-analysis of other studies of the effect of VE supplementation on RFM (Bourne et al., 2008).

The number of post partum metritis cases was $4,1,1$ and 0 in the respective four groups. The number of days required to recover from metritis were 18.5, 15.0 and 7.0 in $\mathrm{T}_{1}, \mathrm{~T}_{2}$ and $\mathrm{T}_{3}$ groups, respectively. Significant effect on the incidence of metritis in cows was reported by giving 3,000 IU VE injections, 8 to $15 \mathrm{~d}$ before parturition (Erskine et al., 1997). Vitamin E supplementation during dry period also reduced the cases of metritis in crossbred cows (Bourne et al., 2008; Chandra and Aggarwal, 2010).

Vitamin E and zinc supplementation increased the DMI, glucose level, and milk yield, whereas, lowers the level of non esterified fatty acid, and thiobarbituric acid reactive substance and maintained the body condition score in peripartum Sahiwal cows.

\section{ACKNOWLEDGEMENTS}

The authors would like to thank the Director, NDRI, Karnal for providing the facilities for the execution of this work. We are grateful to Department of Biotechnology (DBT), New Delhi and 'NICRA' for financial support.

\section{REFERENCES}

Adewuyi, A. A., E. Gruyse, and F. J. van Eerdenburg. 2005. Nonesterified fatty acids (NEFA) in dairy cattle: A review. Vet. Q. 27:117-126.

Balasinska, B. 2004. Evaluation of antioxidant status in living organisms. Med. Weter. 60:579-583.

Bernabucci, U., B. Ronchi, N. Lacetera, and A. Nardone. 2002. Markers of oxidative status in plasma and erythrocytes of transition dairy cows during hot season. J. Dairy Sci. 95:21732179.

Bernabucci, U., B. Ronchi, N. Lacetera, and A. Nardone. 2005. Influence of body condition score on relationships between metabolic status and oxidative stress in periparturient dairy cows. J. Dairy Sci. 88:2017-2026.

Bertics, S., R. Grummer, C. Cadorniga-Valino, and E. Stoddard. 1992. Effect of Prepartum dry matter intake on liver triglyceride concentration and early lactation. J. Dairy Sci. 75: 1914-1922.

Bourne, N., D. C. Wathes, K. E. Lawrence, M. McGowan, and R. A. Laven. 2008. The effect of parenteral supplementation of vitamin $\mathrm{E}$ with selenium on the health and productivity of dairy cattle in the UK. Vet. J. 177:381-387.

Bouwstra, R. J., M. J. Nielen, R. Newbold, E. H. J. M. Jansen, H. F. Jelinek, and T. van Werven. 2010. Vitamin E supplementation during the dry period in dairy cattle. Part II: Oxidative stress following vitamin E supplementation may increase clinical mastitis incidence postpartum. J. Dairy Sci. 93:5696-5706.

Bouwstra, R. J., R. M. A. Goselink, P. Dobbelaar, M. Nielen, J. R. Newbold, and T. Werven. 2008. The relationship between oxidative damage and vitamin E concentration in blood, milk and liver tissue from vitamin $\mathrm{E}$ supplemented and non supplemented periparturient heifers. J. Dairy Sci. 91:977-987.

Boyle, N. O., C. M. Corl, J. C. Gandy, and L. M. Sordillo. 2006. Relationship of body condition score and oxidant stress to tumor necrosis factor expression in dairy cattle. Vet. Immunol. Immunopathol. 113:297-304.

Buckley, F., K. O'Sullivan, J. F. Mee, R. D. Evans, and P. Dillon. 2003. Relationships among milk yield, body condition, cow weight and reproduction in spring-calved Holstein-Friesians. J. Dairy Sci. 86:2308-2319.

Castillo, C., J. Hernandez, A. Bravo, M. Lopez-Alonso, V. Pereira, and J. L. Benedito. 2005. Oxidative status during late pregnancy and early lactation in dairy cows. Vet. J. 169:286292.

Chandra, G., and A. Aggarwal. 2010. Changes in TNF- $\alpha$ levels, metabolic status, milk yield and composition in $\alpha$-tocopherol acetate supplemented high body condition periparturient crossbred cows during different seasons. International conference on physiological capacity building in livestock under changing climate scenario. Vol. II pp. 85. (Abstr)

Chandra, G., A. Aggarwal, A. K. Singh, and M. Kumar. 2012. TNF- $\alpha$ level and metabolic status in $\alpha$-tocopherol acetate supplemented high body condition periparturient crossbred cows during summer and winter season. Indian J. Anim. Sci. 82:999-1003.

Chawla, R., and H. Kaur. 2004. Plasma antioxidant vitamin status of periparturient cows supplemented with $\alpha$-tocopherol and $\beta$-carotene. Anim. Feed Sci. Technol. 114:279-285.

Chen, J. J., and B. P. Yu. 1994. Alteration in mitocondrial membrane fluidity by lipid peroxidation products. Free Radic. Biol. Med. 17:411-418.

Clemens, M. C., and H. D. Waller. 1987. Lipid peroxidation in erythrocytes. Chem. Phys. Lipids 45:251-268.

Contreras, G. A., and L. M. Sordillo. 2011. Lipid mobilization and inflammatory responses during the transition period of dairy cows. Comp. Immunol. Microbiol. Infect. Dis. 34:281-289.

Dann, H. M., D. E. Morin, G. A. Bollero, M. R. Murphy, and J. K. Drackley. 2005. Prepartum intake, postpartum induction of ketosis, and periparturient disorders affect the metabolic status of dairy cows. J. Dairy Sci. 88:3249-3264.

Edmonson, A. J., I. J. Lean, L. D. Weaver, T. Farver, and G. Webster. 1989. A body condition scoring chart for Holstein dairy cows. J. Dairy Sci. 72:68-78.

Erskine, R. J., P. C. Bartlett, T. Herdt, and P. Gaston. 1997. Effects 
of parenteral administration of vitamin $\mathrm{E}$ on health of periparturient dairy cows. J. Am. Vet. Med. Assoc. 211:466469.

Griffiths, L. M., L. H. Loeffler, M. T. Socha, D. J. Tomlinson, and A. B. Johnson. 2007. Effects of supplementing complexed zinc, manganese, copper and cobalt on lactation and reproductive performance of intensively grazed lactating dairy cattle on the south island of New Zealand. Anim. Feed Sci. Technol. 137:69-83.

Grum, D., J. Drackley, R. Younker, D. LaCount, and J. Veenhuizen. 1996. Nutrition during the dry period and hepatic lipid metabolism of periparturient dairy cows. J. Dairy Sci. 79: 1850-1864.

Grummer, R. R., D. G. Mashek, and A. Hayırlı. 2004. Dry matter intake and energy balance in the transition period. Vet. Clin. North Am. Food Anim. Pract. 20:447-470.

Halliwell, B., and S. Chirico. 1993. Lipid peroxidation: its mechanism, measurement, and significance. Am. J. Clin. Nutr. 57:715-724.

Halliwell, B., and M. Whiteman. 2004. Measuring reactive species and oxidative damage in vivo and in cell culture: how should you do it and what do the results mean? Br. J. Pharmacol. 142: 231-255.

Hayirli, A., R. R. Grummer, E. V. Nordheim, and P. M. Crump. 2002. Animal and dietary factors affecting feed intake during the pre-fresh transition period in Holsteins. J. Dairy Sci. 85: 3430-3443.

Ingvartsen, K. L., and J. B. Andersen. 2000. Integration of metabolism and intake regulation: a review focusing on periparturient animals. J. Dairy Sci. 83:1573-1597.

Kim, I. H., and G. H. Suh. 2003. Effect of the amount of body condition loss from the dry to near calving periods on the subsequent body condition change, occurrence of postpartum diseases, metabolic parameters and reproductive performance in Holstein dairy cows. Theriogenology 60:1445-1456.

Komaragiri, M. V., D. P. Casper, and R. A. Erdman. 1998. Factors affecting body tissue mobilization in early lactation of body fat and protein. J. Dairy Sci. 81:169-175.

Kumaraguruparan, R., R. Subapriya, J. Kabalimoorthy, and S. Nagini. 2002. Antioxidant profile in the circulation of patients with fibroadenoma and adenocarcinoma of the breast. Clin. Biochem. 35:275-279.

LeBlanc, S. J., T. H. Herdt, W. M. Seymour, T. F. Duffield, and K. E. Leslie. 2004. Peripartum serum vitamin E, retinol, and $\beta$-carotene in dairy cattle and their associations with disease. J. Dairy Sci. 87:609-619.
Maurya, P. 2011. Leptin level in relation to immunity, energy metabolites and cellular adoptations during dry period and early lactation in crossbred cows. M.V.Sc. Thesis, NDRI (deemed University), Karnal, India.

Miller, J. K., E. Brzezinska-Slebodzinska, and F. C. Madsen. 1993. Oxidative stress, antioxidants, and animal function. J. Dairy Sci. 76:2812-2823.

Panda, N., H. Kaur, and T. K. Mohanty. 2006. Reproductive Performance of dairy buffaloes supplemented with varying levels of vitamin E. Asian-Aust. J. Anim. Sci. 19:19-25.

Park, A. F., J. E. Shirley, E. C. Titgemeyer, R. C. Cochran, J. M. DeFrain, E. E. Wickersham, and D. E. Johnson. 2010. Characterization of plasma metabolites in Holstein dairy cows during the periparturient period. Int. J. Dairy Sci. 5:253-263.

Politis, I., I. Bizelis, A. Tsiaras, and A. Baldi. 2004. Effect of vitamin $\mathrm{E}$ supplementation on neutrophil function, milk composition and plasmin activity in dairy cows in a commercial herd. J. Dairy Res. 71:273-278.

Reist, M., A. Koller, A. Busato, U. Kupfer, and J. Blum. 2000. First ovulation and ketone body status in the early postpartum period of dairy cows. Theriogenology 54:685-701.

Saleh, M., A. Salam, and I. M. H. MEL Mileegy. 2007. Oxidative antioxidant status during transition from late pregnancy to early lactation in native and cross bred cows in the Egyptian oasis. Assiut Vet. Med. J. 53:113.

Shehab-El-Deen, M. A. M. M., M. S. Fadel, A. V. Soom, Y. S. Sherif, D. Maes, M. R. Leroy, and L. Jo. 2010. Circadian rhythm of metabolic changes associated with summer heat stress in high-producing dairy cattle. Trop. Anim. Health Prod. 42:1119-1125.

Sobhanirad, S., D. Carlson, and R. B. Kashani. 2010. Effect of zinc methionine or zinc sulfate supplementation on milk production and composition of milk in lactating dairy cows. Biol. Trace Elem. Res. 136:48-54.

Sordillo, L. M., and S. L. Aitken. 2009. Impact of oxidative stress on the health and immune function of dairy cattle. Vet. Immunol. Immunopathol. 128:104-109.

Sordillo, L. M., G. A. Contreras, and S. L. Aitken 2009. Metabolic factors affecting the inflammatory response of periparturient dairy cows. Anim. Health Res. Rev. 10:53-63.

Sordillo, L. M., N. O'Boyle, J. C. Gandy, C. M. Corl, and E. Hamilton. 2007. Shifts in thioredoxin reductase activity and oxidant status in mononuclear cells obtained from transition dairy cattle. J. Dairy Sci. 90:1186-1192.

Stockdale, C., and J. Roche. 2002. A Review of the energy and protein nutrition of dairy cows through their dry period and its impact on early lactation performance. Aust. J. Agric. Res. 53: 737-753. 